\title{
Thiourea derivatives of Tröger's base: synthesis, enantioseparation and evaluation in organocatalysis of Michael addition to nitroolefins
}

\author{
Delphine Didier $^{\mathrm{a}}$ and Sergey Sergeyev ${ }^{\mathrm{a}, \mathrm{b}_{*}}$ \\ ${ }^{a}$ Université Libre de Bruxelles (ULB), Laboratoire de Chimie des Polymères, CP 206/01, \\ Boulevard du Triomphe, 1050 Brussels, Belgium \\ ${ }^{b}$ University of Antwerp, Department of Chemistry, Groenenborgerlaan 171, 2020 Antwerp, \\ Belgium \\ E-mail: serguei.sergueev@ua.ac.be
}

\begin{abstract}
The catalytic activity of racemic thiourea derivatives of Tröger's base $( \pm)-2-4$ in Michael additions of malonate derivatives to trans- $\beta$-nitrostyrene was studied. Due to the low basicity of Tröger's base, the outcome of the addition reactions was strongly dependent on the $\mathrm{pK}_{\mathrm{a}}$ of the nucleophile. Thiourea catalysts $( \pm)-2,3$ were resolved on the chiral stationary phase Whelk O1. Unfortunately, enantiopure catalysts $\mathbf{2}$ and $\mathbf{3}$ showed no stereoselectivity in the Michael addition.
\end{abstract}

Keywords: Tröger's base, thiourea, Michael addition, catalysis, WhelkO1

\section{Introduction}

In the recent years, asymmetric organocatalysis has emerged as a competitive, environmentfriendlier alternative to catalysis with transition metal complexes. While simple molecules such as derivatives of proline have been receiving a great deal of attention due to their availability, considerable effort has been directed towards searching for novel chiral scaffolds for asymmetric organocatalysis. ${ }^{1}$

Tröger's base $\mathbf{1}$ is a chiral diamine bearing two stereogenic bridge-head nitrogen atoms (Figure 1). The two aromatic rings fused to the central bicyclic framework are almost perpendicular to each other, creating a rigid, $\mathrm{V}$-shaped $\mathrm{C}_{2}$-symmetrical molecular scaffold with a distance of $c a$. $1 \mathrm{~nm}$ between the two extremities. ${ }^{2}$ Due to its chirality and relatively rigid geometry, one would intuitively expect a considerable interest for analogues of Tröger's base in the field of asymmetric synthesis and catalysis. Surprisingly, such applications remain rather limited. For instance, enantiopure Tröger's base or its derivatives demonstrated a moderate to good asymmetric induction as additives in the 1,4 -addition of aryllithium reagent to $\alpha, \beta$ unsaturated esters $(57 \% e e),{ }^{3}$ in the heterogeneous hydrogenation of ethyl pyruvate $(65 \% e e),{ }^{4}$ in 
the addition of $\mathrm{Et}_{2} \mathrm{Zn}$ to benzaldehyde (up to $86 \%$ ee), ${ }^{5}$ and more recently, in the aziridination of chalcones $(62 \% e e){ }^{6}$ In addition, tether-directed functionalization of fullerenes with analogues of Tröger's base as chiral auxiliaries occurred with excellent stereoselectivity. ${ }^{7}$
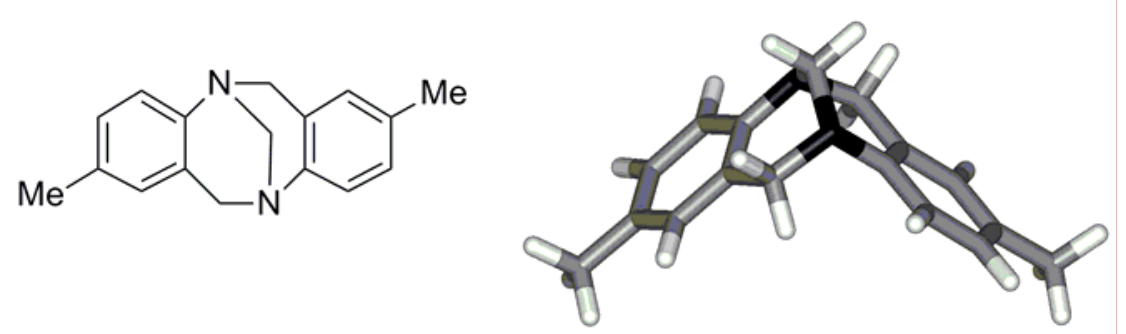

Figure 1. Tröger's base: structural formula (left) and optimized geometry of $(S, S)$-enantiomer (right).

These observations comforted our idea that appropriately modified Tröger's base derivatives might serve as efficient organocatalysts. In particular, our attention was attracted by bifunctional organocatalysts for the Michael addition of 1,3-dicarbonyl compounds to nitroolefins and to $\alpha, \beta$ unsaturated imides introduced by Takemoto and coworkers. ${ }^{8}$ These catalysts comprise two catalytic functions, namely a thiourea and a tertiary amine, connected to a chiral scaffold (e.g., trans-1,2-disubstituted cyclohexane). Since the tertiary amine functions are already incorporated in the chiral scaffold of Tröger's base 1, it appeared plausible to investigate the catalytic activity of thiourea derivatives $( \pm)-2-4$ in the Michael addition to nitroolefins. Furthermore, it would be the first example within this class of catalysts with a nitrogen atom as the center of chirality.

\section{Results and Discussion}

Catalysts $( \pm)-2-4$ were easily prepared from diamines $( \pm)-5$ or $( \pm)-6$ and the corresponding commercially available aryl isothiocyanates in $52-71 \%$ yield (Scheme 1). Intermediates $( \pm$ )-5 and $( \pm)-6$ were prepared in a three steps sequence starting from the commercially available 2bromo-4-methylaniline via a Pd-catalyzed amination or cyanation as reported by us earlier. ${ }^{9}$ 
<smiles>Cc1cc(C=N)c2c(c1)CN1CN(Cc3cc(C)cc(C(F)F)c3-2)CC1CN</smiles>

$( \pm)-5: n=1$

$( \pm)-6: n=0$

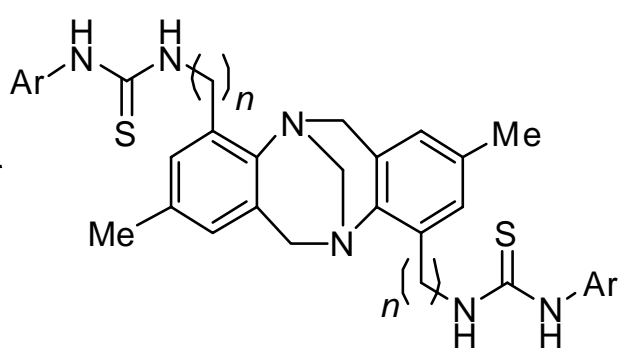

( \pm -2: $n=1, \mathrm{Ar}=\mathrm{Ph}, 52 \%$

( \pm -3: $n=1, \mathrm{Ar}=3,5-\left(\mathrm{CF}_{3}\right)_{2} \mathrm{C}_{6} \mathrm{H}_{3}, 71 \%$

$( \pm)-4: n=0, \mathrm{Ar}=3,5-\left(\mathrm{CF}_{3}\right)_{2} \mathrm{C}_{6} \mathrm{H}_{3}, 60 \%$

Scheme 1. Synthesis of the new thiourea catalysts $( \pm)-2-4$.

At first, we focused on the catalytic activity of racemic thiourea derivatives of Tröger's base for Michael additions. The issue was worth being investigated since the basicity of Tröger's base markedly differs from that of trialkylamines, which are typically used in the design of bifunctional catalysts. We studied the reactivity of thiourea catalysts $( \pm)-2-4$ in a popular and well-studied model reaction, namely, in the addition of selected malonate nucleophiles to trans$\beta$-nitrostyrene. The results obtained are summarized in Table 1.

When trans- $\beta$-nitrostyrene was treated with 2 equivalents of ethylmalonate $7 a$ and $10 \%$ of catalysts $( \pm)-2-4$ in toluene, no conversion was observed (Table 1, entries 3-5). However, the addition of $\mathrm{Et}_{3} \mathrm{~N}$ to the system resulted in a quantitative conversion (Table 1, entry 6). These first results clearly highlighted that the tertiary amines of Tröger's base scaffold $\left(\mathrm{pK}_{\mathrm{a} 1}=3.25\right)^{10}$ are not basic enough to activate the malonate $\left(\mathrm{pK}_{\mathrm{a}}=16.4\right),{ }^{11}$ while more basic $\mathrm{Et}_{3} \mathrm{~N}\left(\mathrm{pK}_{\mathrm{a}}=9.0\right)^{11}$ in the presence of thiourea is highly efficient. This observation supported the early suggested bifunctional mechanism of catalytic activation, ${ }^{8}$ since only $16 \%$ conversion was observed when $\mathrm{Et}_{3} \mathrm{~N}$ was used as a catalyst and no conversion when Tröger's base $( \pm)-\mathbf{1}$ was used as a catalyst (Table 1, entries 1,2).

On the basis of this correlation between $\mathrm{pK}_{\mathrm{a}}$ of the activating base and the rate of conjugate addition, one may expect a higher activity of bifunctional catalysts $( \pm)-2-\mathbf{4}$ for more acidic nucleophiles. Indeed, the reaction of $\mathrm{CH}_{2}(\mathrm{CN})_{2} 7 \mathbf{b}$ with trans- $\beta$-nitrostyrene in the presence of $( \pm)-2-4$ resulted in the formation of the desired product $( \pm)-\mathbf{8 b}$. Prolonged reaction time only slightly increased conversion (Table 1,entries 7-10). Catalyst ( \pm )-3 demonstrated the best performance in the addition of Meldrum's acid 7c to give $( \pm)$-8c (Table 1, entries 15,16). The recurrent inactivity of catalyst $( \pm)-4$ may suggest that the introduction of the additional $\mathrm{CH}_{2}$ linkage in $( \pm)-2,3$ between the aromatic ring and the thiourea provides an additional flexibility to the molecule, which is crucial for the activation of the reagents. 
<smiles>O=[N+]([O-])C=Cc1ccccc1</smiles>

$( \pm)-2-4(10 \%)$, toluene<smiles>[R]C(C[N+](=O)[O-])c1ccccc1</smiles>

$( \pm)-8 \mathbf{a}-\mathbf{c}$ 7,8a: $\mathrm{R}=\mathrm{CH}(\mathrm{COOEt})_{2}$

7,8b: $\mathrm{R}=\mathrm{CH}(\mathrm{CN})_{2}$

$7,8 \mathrm{c}: \mathrm{R}=$

Table 1. Catalytic addition of $\mathbf{7 a - c}$ to trans- $\beta$-nitrostyrene

\begin{tabular}{|c|c|c|c|c|c|c|}
\hline Nucleophile & Entry & Thiourea & Base $^{a}$ & Time (h) & $\mathrm{T}\left({ }^{\circ} \mathrm{C}\right)$ & $\begin{array}{c}\text { Conversion } \\
(\%)^{\mathrm{b}}\end{array}$ \\
\hline $7 a$ & 1 & None & $\mathrm{Et}_{3} \mathrm{~N}$ & 24 & 25 & 16 \\
\hline $7 a$ & 2 & None & $( \pm)-1$ & 24 & 25 & 0 \\
\hline $7 a$ & 3 & $( \pm)-2$ & N.A. & 24 & 25 & 0 \\
\hline $7 a$ & 4 & $( \pm)-3$ & N.A. & 24 & 25 & 0 \\
\hline $7 a$ & 5 & $( \pm)-4$ & N.A. & 24 & 25 & 0 \\
\hline $7 a$ & 6 & $( \pm)-3$ & $\mathrm{Et}_{3} \mathrm{~N}$ & 24 & 25 & 100 \\
\hline $7 b$ & 7 & $( \pm)-2$ & N.A. & 24 & 25 & 53 \\
\hline $7 b$ & 8 & $( \pm)-2$ & N.A. & 144 & 25 & 56 \\
\hline $7 \mathbf{b}$ & 9 & $( \pm)-3$ & N.A. & 24 & 25 & 29 \\
\hline $7 \mathbf{b}$ & 10 & $( \pm)-3$ & N.A. & 144 & 25 & 41 \\
\hline $7 b$ & 11 & $( \pm)-4$ & N.A. & 24 & 25 & 0 \\
\hline $7 \mathbf{b}$ & 12 & $( \pm)-4$ & N.A. & 144 & 25 & 22 \\
\hline 7c & 13 & $( \pm)-2$ & N.A. & 24 & 25 & 0 \\
\hline 7c & 14 & $( \pm)-2$ & N.A. & 24 & 50 & 0 \\
\hline $7 c$ & 15 & $( \pm)-3$ & N.A. & 24 & 25 & 50 \\
\hline $7 c$ & 16 & $( \pm)-3$ & N.A. & 24 & 50 & 100 \\
\hline 7c & 17 & $( \pm)-4$ & N.A. & 144 & 25 & 23 \\
\hline $7 c$ & 18 & $( \pm)-4$ & N.A. & 24 & 50 & 33 \\
\hline
\end{tabular}

${ }^{a}$ The reaction was conducted with $10 \%$ of base, when applicable.

${ }^{b}$ Determined by ${ }^{1} \mathrm{H}$ NMR vs. trans- $\beta$-nitrostyrene.

Next, the enantioselectivity of the new thiourea catalysts was evaluated. Due to its low activity, catalyst $( \pm)-\mathbf{4}$ was excluded from this study. Catalysts $( \pm)-2,3$ were resolved by preparative chiral HPLC. Chromatographic separation of enantiomers was performed on the commercial chiral stationary phase (CSP) Whelk O1, with a covalently bound chiral selector derived from 3,4-disubstituted 1,2,3,4-tetrahydrophenanthrene (Figure 2). Originally developed by Pirkle and co-workers ${ }^{12}$ for the separation of naproxene and other non-steroidal antiinflammatory drugs (NSAIDS), this CSP has later become increasingly popular due to its broad versatility. Due to conformational preferences of the saturated ring in 1,2,3,4tetrahydrophenanthrene (half-chair with the pseudoaxial amide group), the chiral selector of 
Whelk O1 has a cleft-like shape. Preferential binding of the more retained enantiomer of a chiral analyte in the cleft is provided through simultaneous face-to-face $\pi$ - $\pi$ interactions with the $\pi$ acidic 3,5-dinitrobenzoyl moiety, face-to-edge $\mathrm{CH}-\pi$ binding with the $\pi$-basic naphthalene system and $\mathrm{H}$-bonding with the hydrogen of the amide group. The less retained enantiomer is incapable of all these interactions without inducing a deviation from the lowest-energy conformation. Therefore, a typical good analyte for Whelk O1 CSP is an aromatic system with an additional H-bond acceptor in the proximity of the chiral center.

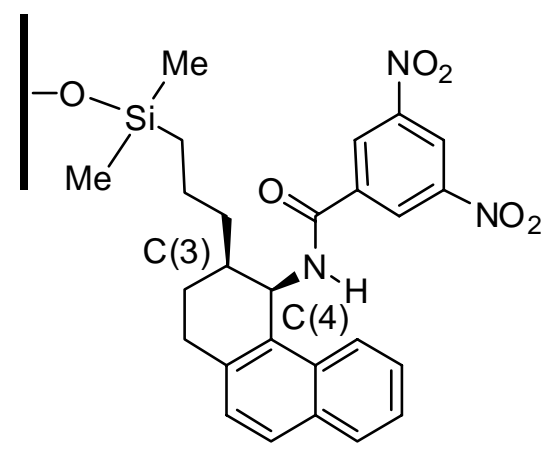

Figure 2. Chemical structure of CSP $(3 S, 4 R)$ Whelk O1 used in this study.

This CSP is marketed by Regis Technologies, Inc. under the name $(R, R)$-Whelk O1. The absolute configuration of the chiral selector is thus incorrectly designated, but this should not lead to confusion. Decisive is the relative stereochemistry of the two stereogenic carbon atoms (cis) and the correct designation of the absolute configuration of C(4). Incorrect designation of the absolute configuration of $\mathrm{C}(3)$ results from the fact that the original version of this CSP had an eleven-carbon linker, but substitution of it by the three-carbon linker results in the inversion of Cahn-Ingold-Prelog priorities at C(3). ${ }^{13}$

In the recent studies, ${ }^{14,15}$ we demonstrated that CSP Whelk O1 is rather versatile for the separation of Tröger's base analogues, in which the chiral center itself (stereogenic N-atom) serves as an H-bond acceptor. Moreover, systematic separation of a library of Tröger's base analogues allowed us to build a predictive model which is based on simple mechanistic considerations. ${ }^{14}$ In particular, we concluded that substituents on the aromatic rings in orthopositions to the $\mathrm{N}$-atoms greatly decrease the enantioselectivity due to sterical constraints, unless they are efficient H-bond donors (e.g. $\mathrm{NH}_{2}$ or $\mathrm{OH}$ groups). In the latter case the enantioselectivity is increased, presumably due to additional H-bonding with the carbonyl group of the chiral selector.

Thioureas $( \pm)-2,3$ provided a good occasion to evaluate the predictive capacity of our model. Since thiourea is an efficient H-bond donor, we expected reasonable enantioselectivity in spite of the presence of substituents in ortho-positions to the $\mathrm{N}$-atoms. However, long retention times due to strong achiral interactions with the underlying silica support were expected. Indeed, the 
behavior of thiourea derivatives $\mathbf{2}$ and $\mathbf{3}$ on Whelk $\mathrm{O} 1$ was in good agreement with this prediction (Table 2 and Figure 3).

Table 2. Separation parameters for preparative HPLC of $( \pm)-2$ and ( \pm )-3 on CSP Whelk O1 and their chiroptical properties

\begin{tabular}{|c|c|c|c|c|c|c|}
\hline $\begin{array}{l}\text { Thiourea } \\
\text { derivative }\end{array}$ & $\begin{array}{c}\text { Mobile phase } \\
\text { (hexane/i-PrOH, } \mathrm{v} / \mathrm{v} \text { ) }\end{array}$ & $k_{1}$ & $\alpha$ & $R_{\mathrm{s}}$ & {$[\alpha]_{\mathrm{D}}^{25}(c)^{\mathrm{a}, \mathrm{b}}$} & $\begin{array}{c}\Delta \varepsilon, \mathrm{cm}^{2} \mathrm{mmol}^{-1} \\
\left(\lambda_{\max }, \mathrm{nm}\right)^{\mathrm{a}, \mathrm{b}}\end{array}$ \\
\hline 2 & $0: 100$ & 4.56 & 184 & 14 & $-39(0.127)$ & $-2.6(292)$ \\
\hline 2 & $0: 100$ & 4.50 & 1.84 & 1.4 & $+39(0.127)$ & $+2.6(292)$ \\
\hline 3 & $85: 15$ & 3.21 & 1.62 & 1.7 & $\begin{array}{l}-94(0.311) \\
+93(0.276)\end{array}$ & $\begin{array}{l}-8.9(290) \\
+8.7(290)\end{array}$ \\
\hline
\end{tabular}

${ }^{\text {a }}$ Data for the two enantiomers indicated according to their order of elution.

${ }^{\mathrm{b}}$ Measured in $\mathrm{CH}_{2} \mathrm{Cl}_{2}$.

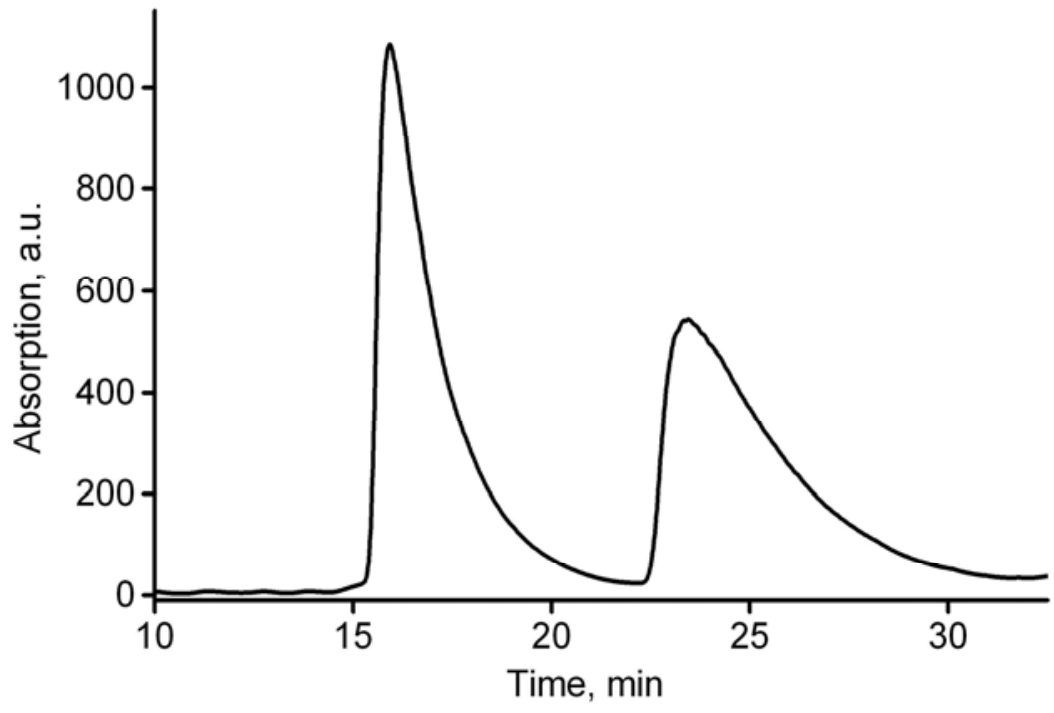

Figure 3. Chromatogram of $( \pm)-3$ on Whelk O1.

The signs of the lowest energy band in CD spectra of $\mathbf{2}$ and $\mathbf{3}$ were compared to those of enantiomerically pure 1 (Figure 4). As it was shown by Kostyanovsky and co-workers, such a comparison may be used for the assignment of the absolute configuration of Tröger's base derivatives. ${ }^{16}$ Hence, the absolute configuration of the first eluted enantiomer can tentatively be assigned as (-)-(S,S)-2 and (-)-(S,S)-3. However, the comparison of CD spectra even in series of derivatives should be used with great reservation, especially for derivatives with a different substitution pattern, as demonstrated by Lützen and co-workers. ${ }^{17}$ Hence, we intended to take advantage of the presence of heavy sulfur atoms in $\mathbf{2}$ and $\mathbf{3}$ for the assignment of their absolute 
configuration via "anomalous X-ray scattering". ${ }^{18}$ Unfortunately, we were not able to grow suitable crystals for XRD measurements.

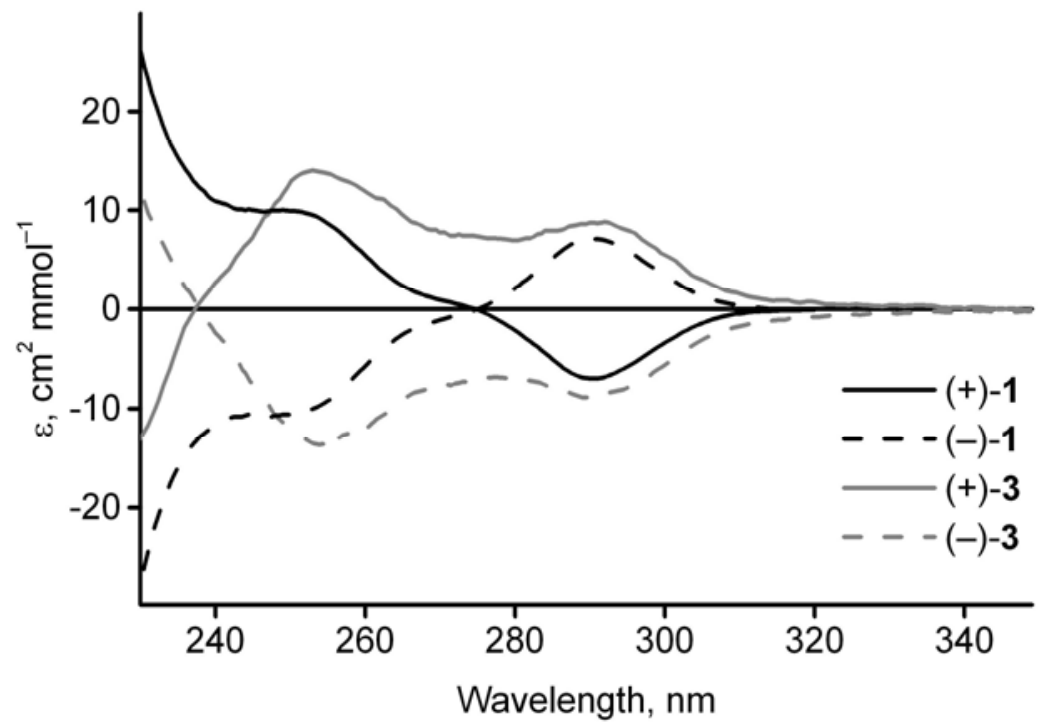

Figure 4. CD spectra of $\mathbf{1}$ and $\mathbf{3}$ in $\mathrm{MeOH}$.

With enantiopure thiourea catalysts 2 and 3 in hand we evaluated their stereoselectivity in the Michael addition of ethylmalonate 7a, $\mathrm{CH}_{2}(\mathrm{CN})_{2} \mathbf{7 b}$ and Meldrum's acid 7c to trans- $\beta$ nitrostyrene. Enantiomeric excess (ee) of products was analysed as described before by HPLC. ${ }^{19}$

First, Tröger's base (+)-1 was used as a catalyst in the addition of $\mathrm{CH}_{2}(\mathrm{CN})_{2} \mathbf{7 b}$ to trans- $\beta$ nitrostyrene to give $\mathbf{8 b}$, but no stereoselectivity was observed. After reaction Tröger's base (+)-1 was recovered in $83 \%$ ee. Hence, the lack of stereoselectivity is not due to racemization of the catalyst.

The enantiopure catalysts $(+)-2,(-)-2,(+)-3$ and $(-)-3$ were evaluated next in the reactions of 7a-c with trans- $\beta$-nitrostyrene in the same conditions as found for racemic catalysts (Table 1 , entries 6-10,15,16). Unfortunately, no measurable stereoselectivity was found: $e e<5 \%$ was detected for products $\mathbf{8 a}-\mathbf{c}$ with all catalysts.

\section{Conclusions}

Thiourea derivatives of Tröger's base ( \pm )-2-4 were synthesized and evaluated, both in racemic and enantiomerically pure form, as organocatalysts for the Michael additions of malonate derivatives to trans- $\beta$-nitrostyrene. The bifunctional mechanism of this catalytic system, based on the complementarities of the tertiary amine and the thiourea, was demonstrated. The outcome of the addition reactions was found to be strongly dependent on the $\mathrm{pK}_{\mathrm{a}}$ of the malonate nucleophiles. Although high (up to quantitative) conversions were observed for more acidic nucleophiles $\left(\mathrm{CH}_{2}(\mathrm{CN})_{2}\right.$ and Meldrum's acid), no measurable stereoselectivity was found. 
Notwithstanding this, prepared by us enantiomerically pure thiourea derivatives of Tröger's base might prove useful for other applications.

\section{Experimental Section}

General. All chemicals were purchased from Aldrich or Acros and used without further purification unless stated otherwise. Diamines $( \pm)-5$ and $( \pm)-6$ were prepared by published procedures. $^{9,20}$ THF was refluxed over sodium and benzophenone until a blue-violet color persisted and distilled directly into the reaction flask. All reactions were performed in oven-dry glassware under dry Ar atmosphere. Column chromatography: $\mathrm{SiO}_{2}$ Kieselgel 60 (MachereyNagel, particle size 0.04-0.063 mm). TLC: precoated $\mathrm{SiO}_{2}$ plates Kieselgel 60F254 (Merck). IR spectra were recorded on a Shimadzu IR-470 instrument in $\mathrm{KBr}$ pellets. ${ }^{1} \mathrm{H}-\mathrm{NMR}(300 \mathrm{MHz})$ and ${ }^{13} \mathrm{C}$-NMR $(75 \mathrm{MHz})$ spectra were recorded in $\mathrm{CDCl}_{3}$ on a Brucker Avance 300 spectrometer; chemical shifts $(\delta)$ are given in ppm relative to $\mathrm{Me}_{4} \mathrm{Si}$. Electrospray ionization mass spectra (ESIMS) were recorded on a Waters QToF 2 instrument; $m / z$ with the lowest isotopic mass are reported. Optical rotations were measured on a Perkin Elmer 141 polarimeter, values are given in $10^{-1} \mathrm{~cm}^{2} \mathrm{~g}^{-1} ; 10 \mathrm{~cm}$ cell at r.t. Circular dichroism spectra were measured on a Jasco J-710 spectropolarimeter; $1 \mathrm{~cm}$ cell at r.t.

Analytical HPLC separations were performed at ambient temperature on an Agilent 1100 instrument equipped with a G1313A automatic injector. Mobile phase hexane $/ i$-PrOH, nominal flow rate $2.0 \mathrm{~mL} \mathrm{~min}{ }^{-1}$; detection: UV at fixed wavelength 254 or $230 \mathrm{~nm}$. Preparative HPLC separations were performed at ambient temperature on an Agilent 1100 instrument equipped with a Rheodyne 7725 manual injector. Mobile phase hexane $/ i-\mathrm{PrOH}$, nominal flow rate $10.0 \mathrm{~mL}$ $\mathrm{min}^{-1}$; detection: UV at fixed wavelength 254 or $230 \mathrm{~nm}$. Columns $(R, R)$-Whelk-O1 $(250 \times 4.6$ $\mathrm{mm}$ for analytical and $250 \times 21.1 \mathrm{~mm}$ for preparative separations) were purchased from Regis Technologies (USA). Separation parameters were calculated as follows: $k_{1}=\left(t_{1}-t_{0}\right) / t_{0}, k_{2}=\left(t_{2}-\right.$ $\left.t_{0}\right) / t_{0}, \alpha=k_{2} / k_{1}, R_{\mathrm{s}}=2\left(t_{2}-t_{1}\right) /\left(w_{2}+w_{1}\right)$, where $t_{1}, t_{2}$ are retention times of the two enantiomers, $t_{0}$ is the void time (retention time of 1,3,5-tri-tert-butylbenzene), $k_{1}, k_{2}$ are the retention factors of the two enantiomers, $\alpha$ is the separation factor, $w_{1}, w_{2}$ are the widths of peaks at the base line, and $R_{\mathrm{S}}$ is the resolution at the base line.

\section{General procedure for the synthesis of thiourea catalysts}

All reactions were performed under dry Ar in oven-dry glassware. A solution of diamine $( \pm)-5$ or $( \pm)$-6 (prepared as described previously) ${ }^{9}$ in dry THF was treated with an aryl isothiocyanate at 0 ${ }^{\circ} \mathrm{C}$. The mixture was stirred for $10 \mathrm{~min}$ at $0{ }^{\circ} \mathrm{C}$, allowed to reach room temperature, and stirred for a further $24 \mathrm{~h}$. The solvent was removed in vacuum and the resulting solid was purified by column chromatography or by crystallization from $\mathrm{CH}_{2} \mathrm{Cl}_{2}$.

( \pm )-1-[2,8-Dimethyl-10-[(3-phenylthioureido)methyl]-6H,12H-5,11methanodibenzo[b,f][1,5] diazocin-4-ylmethyl]-3-phenylthiourea ( \pm )-2. Synthesized following the general procedure 
from $( \pm)-5(57.5 \mathrm{mg}, 0.186 \mathrm{mmol})$ and phenyl isothiocyanate $(60 \mathrm{mg}, 0.444 \mathrm{mmol})$ in dry THF (1.5 mL). Purification by column chromatography $\left(\mathrm{CH}_{2} \mathrm{Cl}_{2}\right.$, then $\left.\mathrm{CH}_{2} \mathrm{Cl}_{2} / \mathrm{AcOEt}(8: 2)\right)$ afforded $( \pm)-2(56.0 \mathrm{mg}, 52 \%)$ as a white solid; $\mathrm{mp} 248{ }^{\circ} \mathrm{C}\left(\mathrm{dec}\right.$.). IR $(\mathrm{KBr})\left(v_{\max } / \mathrm{cm}^{-1}\right): 3350 \mathrm{~m}, 3182 \mathrm{~m}$, $3010 \mathrm{~m}, 1525 \mathrm{~s}, 1481 \mathrm{~s}, 1425 \mathrm{~m}, 1282 \mathrm{~m}, 1213 \mathrm{~m}, 1276 \mathrm{vs}, 1118 \mathrm{w}, 1135 \mathrm{~s}, 1025 \mathrm{w}, 914 \mathrm{w}, 860 \mathrm{w}$, $709 \mathrm{w}, 667 \mathrm{~m} .{ }^{1} \mathrm{H}$ NMR (DMSO- $\left.d_{6}, 80{ }^{\circ} \mathrm{C}\right): \delta=2.18(\mathrm{~s}, 6 \mathrm{H}), 3.98\left(\mathrm{~d},{ }^{2} J_{\mathrm{H}, \mathrm{H}}=16.8 \mathrm{~Hz}, 2 \mathrm{H}\right), 4.08$ $(\mathrm{s}, 2 \mathrm{H}), 4.50\left(\mathrm{~d},{ }^{2} J_{\mathrm{H}, \mathrm{H}}=16.8 \mathrm{~Hz}, 2 \mathrm{H}\right), 4.74\left(\mathrm{dd},{ }^{2} J_{\mathrm{H}, \mathrm{H}}=15.3 \mathrm{~Hz},{ }^{3} J_{\mathrm{H}, \mathrm{H}}=3.3 \mathrm{~Hz}, 2 \mathrm{H}\right), 4.97(\mathrm{dd}$, $\left.{ }^{2} J_{\mathrm{H}, \mathrm{H}}=15.3 \mathrm{~Hz},{ }^{3} J_{\mathrm{H}, \mathrm{H}}=6.3 \mathrm{~Hz}, 2 \mathrm{H}\right), 6.68(\mathrm{~s}, 2 \mathrm{H}), 6.97(\mathrm{~s}, 2 \mathrm{H}), 7.04-7.20(\mathrm{~m}, 2 \mathrm{H}), 7.24-7.40$ (m, $4 \mathrm{H}), 7.40-7.56(\mathrm{~m}, 4 \mathrm{H}), 8.05$ (br t, $2 \mathrm{H}, \mathrm{NH}), 9.50$ (br s, $2 \mathrm{H}, \mathrm{NH}) .{ }^{13} \mathrm{C}$ NMR (DMSO- $d_{6}$, $\left.80{ }^{\circ} \mathrm{C}\right): \delta=20.0\left(2 \mathrm{CH}_{3}\right), 43.2\left(2 \mathrm{CH}_{2}\right), 54.8\left(2 \mathrm{CH}_{2}\right), 66.3\left(1 \mathrm{CH}_{2}\right), 123.0(4 \mathrm{CH}), 123.9(2 \mathrm{CH})$, $125.6(2 \mathrm{C}), 127.0(2 \mathrm{C}), 127.4(2 \mathrm{CH}), 128.1(4 \mathrm{CH}), 131.8(2 \mathrm{CH}), 132.3(2 \mathrm{C}), 138.9(2 \mathrm{C})$, 142.2 (2 C), 180.6 (2 C). HRESIMS: $m / z$ : calc. for $\mathrm{C}_{33} \mathrm{H}_{35} \mathrm{~N}_{6} \mathrm{~S}_{2}\left([M+\mathrm{H}]^{+}\right)$: 579.2365 ; found: 579.2357 .

\section{( \pm )-1-(3,5-Bistrifluoromethylphenyl)-3-[2,8-dimethyl-10-[(3-(3,5-bistrifluoromethylphenyl)} thioureido)methyl]-6H,12H-5,11-methanodibenzo[b,f][1,5]diazocin-4-ylmethyl]thiourea

$( \pm)$-3. Synthesized following the general procedure from $( \pm)-5(0.552 \mathrm{~g}, 1.79 \mathrm{mmol})$ and 3,5bis(trifluoromethyl)phenyl isothiocyanate $(0.970 \mathrm{~g}, 3.58 \mathrm{mmol})$ in dry THF $(16 \mathrm{~mL})$. Purification by flash chromatography $\left(\mathrm{CH}_{2} \mathrm{Cl}_{2}\right)$ afforded $( \pm)-3(1.082 \mathrm{~g}, 71 \%)$ as a white solid; mp $190{ }^{\circ} \mathrm{C}$ (dec.). IR (KBr) $\left(v_{\max } / \mathrm{cm}^{-1}\right): 3350 \mathrm{~m}, 3175 \mathrm{~m}, 3010 \mathrm{~m}, 1731 \mathrm{w}, 1592 \mathrm{w}, 1515 \mathrm{~m}, 1473 \mathrm{~s}, 1380 \mathrm{~s}$, $1274 \mathrm{vs}, 1180 \mathrm{~m}, 1130 \mathrm{vs}, 981 \mathrm{w}, 887 \mathrm{~m} .{ }^{1} \mathrm{H}$ NMR (DMSO- $\left.d_{6}, 80{ }^{\circ} \mathrm{C}\right): \delta=2.22(\mathrm{~s}, 6 \mathrm{H}), 4.05(\mathrm{~d}$, $\left.{ }^{2} J_{\mathrm{H}, \mathrm{H}}=17.2 \mathrm{~Hz}, 2 \mathrm{H}\right), 4.28(\mathrm{~s}, 2 \mathrm{H}), 4.62\left(\mathrm{~d},{ }^{2} J_{\mathrm{H}, \mathrm{H}}=17.2 \mathrm{~Hz}, 2 \mathrm{H}\right), 4.87\left(\mathrm{dd},{ }^{2} J_{\mathrm{H}, \mathrm{H}}=15.6 \mathrm{~Hz}\right.$, $3 J \mathrm{H}, \mathrm{H}=4.5 \mathrm{~Hz}, 2 \mathrm{H}), 5.01\left(\mathrm{dd},{ }^{2} J_{\mathrm{H}, \mathrm{H}}=15.6 \mathrm{~Hz},{ }^{3} J_{\mathrm{H}, \mathrm{H}}=5.6 \mathrm{~Hz}, 2 \mathrm{H}\right), 6.76(\mathrm{~s}, 2 \mathrm{H}), 7.04(\mathrm{~s}, 2 \mathrm{H})$, 7.70 (s, $2 \mathrm{H}$ ), 8.35 (s, $4 \mathrm{H}$ ), 8.43 (br t, $2 \mathrm{H}, \mathrm{NH}$ ), 10.06 (br s, $2 \mathrm{H}, \mathrm{NH}) .{ }^{13} \mathrm{C}$ NMR (DMSO- $d_{6}, 80$ $\left.{ }^{\circ} \mathrm{C}\right): \delta=21.0\left(2 \mathrm{CH}_{3}\right), 43.8\left(2 \mathrm{CH}_{2}\right), 56.2\left(2 \mathrm{CH}_{2}\right), 67.5\left(1 \mathrm{CH}_{2}\right), 116.3-116.9(\mathrm{~m}, 2 \mathrm{CH}), 123.9$ (q, $\left.{ }^{1} J_{\mathrm{C}, \mathrm{F}}=271.4 \mathrm{~Hz}, 4 \mathrm{C}\right), 122.4-123.0(\mathrm{~m}, 4 \mathrm{CH}), 126.8(2 \mathrm{C}), 127.9(2 \mathrm{C}), 128.6(2 \mathrm{CH}), 130.9$ (q, $\left.{ }^{2} J_{\mathrm{C}, \mathrm{F}}=32.9 \mathrm{~Hz}, 4 \mathrm{C}\right), 132.5(2 \mathrm{CH}), 133.4(2 \mathrm{C}), 142.8(2 \mathrm{C}), 143.5(2 \mathrm{C}), 181.8(2 \mathrm{C})$. HRESIMS: $m / z$ : calc. for $\mathrm{C}_{37} \mathrm{H}_{31} \mathrm{~F}_{12} \mathrm{~N}_{6} \mathrm{~S}_{2}\left([M+\mathrm{H}]^{+}\right): 851.1860$; found: 851.1841 .

\section{( \pm -1-[3,5-Bis(trifluoromethyl)phenyl]-3-[10-(3-[3,5-bis(trifluoromethyl)phenyl]thioureido)-2,8-dimethyl-}

$6 H, 12 H-5,11-m e t h a n o d i b e n z o[b, f][1,5]$ diazocin-4-yl]-thiourea $( \pm)-4$. Synthesized following the general procedure from $( \pm)-6(138 \mathrm{mg}, 0.492 \mathrm{mmol})$ and 3,5-bis(trifuoromethyl)phenyl isothiocyanate (267 mg, $0.985 \mathrm{mmol}$ ) in dry THF $(5 \mathrm{~mL})$. The crude product was crystallized from $\mathrm{CH}_{2} \mathrm{Cl}_{2}$ to give the analytically pure $( \pm)-4$ as a white solid $(244 \mathrm{mg}, 60 \%) ; \mathrm{mp} 280{ }^{\circ} \mathrm{C}(\mathrm{dec})$. IR $(\mathrm{KBr})$ $\left(v_{\max } / \mathrm{cm}^{-1}\right): 3345 \mathrm{~m}, 3175 \mathrm{~m}, 3010 \mathrm{~m}, 1611 \mathrm{~m}, 1524 \mathrm{~s}, 1464 \mathrm{~s}, 1437 \mathrm{~m}, 1383 \mathrm{~s}, 1333 \mathrm{~m}, 1276 \mathrm{vs}$, $1180 \mathrm{~s}, 1135 \mathrm{~s}, 1108 \mathrm{~m}, 919 \mathrm{~m}, 884 \mathrm{~m}, 678 \mathrm{~m} .{ }^{1} \mathrm{H}$ NMR (DMSO-d $\left.{ }_{6}\right): \delta=2.19(\mathrm{~s}, 6 \mathrm{H}), 3.93\left(\mathrm{~d},{ }^{2} J_{\mathrm{H}, \mathrm{H}}\right.$ $=16.8 \mathrm{~Hz}, 2 \mathrm{H}), 4.32(\mathrm{~s}, 2 \mathrm{H}), 4.54\left(\mathrm{~d},{ }^{2} J_{\mathrm{H}, \mathrm{H}}=16.8 \mathrm{~Hz}, 2 \mathrm{H}\right), 6.67(\mathrm{~s}, 2 \mathrm{H}), 7.48(\mathrm{~s}, 2 \mathrm{H}), 7.82(\mathrm{~s}$, $2 \mathrm{H}), 8.40$ (s, $4 \mathrm{H}), 9.64(\mathrm{~s}, 2 \mathrm{H}), 10.64(\mathrm{~s}, 2 \mathrm{H}) .{ }^{13} \mathrm{C}$ NMR (DMSO-d 6 ): $\delta=20.5\left(2 \mathrm{CH}_{3}\right), 54.4(2$ $\left.\mathrm{CH}_{2}\right), 66.0\left(1 \mathrm{CH}_{2}\right), 116.6-116.9(\mathrm{~m}, 2 \mathrm{CH}), 123.2\left(\mathrm{q},{ }^{1} J_{\mathrm{C}, \mathrm{F}}=272.8 \mathrm{~Hz}, 4 \mathrm{C}\right), 122.7-123.0(\mathrm{~m}, 4$ $\mathrm{CH}), 124.5(2 \mathrm{C}), 124.7(2 \mathrm{C}), 128.5(2 \mathrm{CH}), 130.0$ (q, $\left.{ }^{2} J_{\mathrm{C}, \mathrm{F}}=32.9 \mathrm{~Hz}, 4 \mathrm{C}\right), 132.0(2 \mathrm{CH}), 132.6$ (2 C), 138.0 (2 C), 141.7 (2 C), 179.4 (2 C). HRESIMS: $m / z$ : calc. for $\mathrm{C}_{35} \mathrm{H}_{27} \mathrm{~N}_{6} \mathrm{~F}_{12} \mathrm{~S}_{2}\left([M+\mathrm{H}]^{+}\right)$: 823.1547; found: 823.1544. 


\section{Acknowledgements}

S. Sergeyev is indebted to Prof. Y. Geerts (ULB) for the opportunity to conduct an independent research program in his laboratory. This study was supported by FNRS (grant 1.5.110.08 and contract of "Collaborateur scientifique" for S. Sergeyev). We thank A. Remacle for help with measurements.

\section{References}

1. Berkessel, A.; Groerger, H. Asymmetric Organocatalysis; Wiley-VCH: Weinheim, 2005; Dalko, P. I. Enantioselective Organocatalysis; Wiley-VCH: Weinheim, 2007; Almasi, D.; Alonso, D. A.; Najera, C. Tetrahedron: Asymmetry 2007, 18, 299; Guillena, G.; Najera, C.; Ramon, D. J. Tetrahedron: Asymmetry 2007, 18, 2249; MacMillan, D. W. C. Nature 2008, 455, 304.

2. Dolenský, B.; Elguero, J.; Král, V.; Pardo, C.; Valík, M. Adv. Heterocycl. Chem. 2007, 93, 1. Sergeyev, S. Helv. Chim. Acta 2009, 92, 415.

3. Xu, F.; Tillyer, R. D.; Tschaen, D. M.; Grabowski, E. J. J.; Reider, P. J. Tetrahedron: Asymmetry 1998, 9, 1651.

4. Minder, B.; Schürch, M.; Mallat, T.; Baiker, A. Catal. Lett. 1995, 31, 143.

5. Harmata, M.; Kahraman, M. Tetrahedron: Asymmetry 2000, 11, 2875.

6. Shen, Y.-M.; Zhao, M.-X.; Xu, J.; Shi, Y. Angew. Chem., Int. Ed. 2006, 45, 8005.

7. Sergeyev, S.; Diederich, F. Angew. Chem., Int. Ed. 2004, 43, 1738; Sergeyev, S.; Schär, M.; Seiler, P.; Lukoyanova, O.; Echegoyen, L.; Diederich, F. Chem. Eur. J. 2005, 11, 2284.

8. Okino, T.; Hoashi, Y.; Takemoto, Y. J. Am. Chem. Soc. 2003, 125, 12672. Hoashi, Y.; Okino, T.; Takemoto, Y. Angew. Chem., Int. Ed. 2005, 44, 4032. Inokuma, T.; Hoashi, Y.; Takemoto, Y. J. Am. Chem. Soc. 2006, 128, 9413.

9. Didier, D.; Sergeyev, S. Tetrahedron 2007, 63, 3864.

10. Wepster, B. M. Recl. Trav. Chim. Pays-Bas 1953, 72, 661.

11.Bordwell, F. G. Acc. Chem. Res. 1988, 21, 456.

12.Pirkle, W. H.; Welch, C. J.; Lamm, B. J. Org. Chem. 1992, 57, 3854; Pirkle, W. H.; Welch, C. J. J. Liq. Chromatogr. 1992, 15, 1947.

13.Pirkle, W. H.; Brice, L. J.; Widlanski, T. S.; Roestamadji, J. Tetrahedron: Asymmetry 1996, 7, 2173.

14.Didier, D.; Tylleman, B.; Lambert, N.; Vande Velde, C. M. L.; Blockhuys, F.; Collas, A.; Sergeyev, S. Tetrahedron 2008, 64, 6252.

15.Sergeyev, S.; Stas, S.; Remacle, A.; Vande Velde, C. M. L.; Dolensky, B.; Havlik, M.; Kral, V.; Cejka, J. Tetrahedron: Asymmetry 2009, 20, 1918.

16.Lenev, D. A.; Lyssenko, K. A.; Golovanov, D. G.; Malyshev, O. R.; Levkin, P. A.; Kostyanovsky, R. G. Tetrahedron Lett. 2006, 47, 319. 
17.Kiehne, U.; Bruhn, T.; Schnakenburg, G.; Fröhlich, R.; Bringmann, G.; Lützen, A. Chem. Eur. J. 2008, 14, 4246.

18.Flack, H. D.; Bernardinelli, G. Chirality 2008, 20, 681.

19.Okino, T.; Hoashi, Y.; Furukawa, T.; Xu, X.; Takemoto, Y. J. Am. Chem. Soc. 2005, 127, 119. McGarraugh, P. G.; Brenner, S. E. Tetrahedron 2009, 65, 449; Andrés, J. M.; Pedrosa, R. M. R. Chem. Eur. J. 2008, 14, 5116.

20.Sergeyev, S.; Diederich, F. Chirality 2006, 18, 707. 